\title{
Determination of Emtricitabine by Derivative Spectrophotometric Method in Pharmaceutical Dosage Forms
}

\author{
A. NARENDRA ${ }^{* a}$, D. DEEPIKA ${ }^{\mathrm{b}}$ and M. MATHRUSRI ANNAPURNA ${ }^{\mathrm{c}}$ \\ ${ }^{a}$ Micro Advanced Research Centre, Bangalore, Karnataka, India \\ ${ }^{b}$ Vijaya Institue of Pharmaceutical Sciences for Women, Vijayawada, A.P, India \\ ${ }^{\mathrm{c}}$ GITAM Institute of Pharmacy, GITAM University, Visakhapatnam, A.P., India \\ naren_angirekula@yahoo.com
}

Received 13 December 2012 / Accepted 13 January 2013

\begin{abstract}
Three simple, precise and accurate spectrophotometric methods have been developed for the estimation of emtricitabine in bulk and pharmaceutical formulations. Emtricitabine exhibits maximum absorbance at $282.0 \mathrm{~nm}$ in method A. The amplitude shows at $269.0-298.0 \mathrm{~nm}$ in method B and method C is based on calculation of area under curve (AUC) in the wavelength region of 272.0-292.0 nm. The drug obeys the Beer-Lambert's law in the concentration range of $1.0-100 \mu \mathrm{g} / \mathrm{mL}$ in all three methods. The methods were validated by following the analytical performance parameters suggested by the International Conference on Harmonization. All validation parameters were within the acceptable range. The developed methods were successfully applied to estimate the amount of emtricitabine in bulk and pharmaceutical dosage forms.
\end{abstract}

Keywords: Emtricitabine, Derivative spectroscopy, Area under curve

\section{Introduction}

Emtricitabine $^{1}$ chemically, 4-amino-5-fluoro-1-[(2S, 5R)-2-(hydroxymethyl)-1,3-oxathiolan-5yl]-1,2-dihydropyrimidin-2-one having molecular formula $\mathrm{C}_{8} \mathrm{H}_{10} \mathrm{FN}_{3} \mathrm{O}_{3} \mathrm{~S}$ (Figure 1) is an nucleoside reverse transcriptase inhibitor (NRTI) for the treatment of HIV infection in adults. Emtricitabine is an analogue of cytidine. The drug works by inhibiting reverse transcriptase, the enzyme that copies HIV RNA into new viral DNA. The different analytical methods that are reported for its determination includes $\mathrm{HPLC}^{2-7}, \mathrm{LC} \mathrm{MS}^{8,9}$ and spectroscopy ${ }^{10,11}$. The aim of the present work is to develop new validated spectrophotometric methods for the estimation of emtricitabine in bulk and pharmaceutical dosage forms.<smiles>N/C=C(/N)N(C=O)C1CSC2COC1CO2</smiles>

Figure 1. Chemical structure of emtricitabine 


\section{Experimental}

Emtricitabine gift sample was supplied by Piramal HC (India) and commercial capsule formulations from the local market were purchased from local market. Methanol (Merck), Octane-1 sulfonic acid sodium salt (Spectrochem) and ortho phosphoric acid (AR) (Merck) were used in the present study.

\section{Instrumentation}

A double beam UV-Vis spectrophotometer (UV- 1800, Shimadzu, Japan) connected to computer loaded with spectra manager software UV Probe was employed with spectral band-width of $1 \mathrm{~nm}$ wavelength accuracy of $\pm 0.3 \mathrm{~nm}$ with a pair of $10 \mathrm{~mm}$ matched quartz cells. All weights were taken on electronic balance (Denver, Germany).

\section{Preparation of stock solution}

The stock solution of emtricitabine was prepared by dissolving accurately $25 \mathrm{mg}$ of drug in methanol in a $25 \mathrm{~mL}$ volumetric flask to obtain a concentration of $1000 \mu \mathrm{g} / \mathrm{mL}$. From this solution, $2.5 \mathrm{~mL}$ was taken and diluted with $0.02 \mathrm{M}$ Octane 1- sulfonic acid buffer ( $\mathrm{pH} 3.5$ adjusted with $o$-phosphoric acid) in a $25 \mathrm{~mL}$ volumetric flask to prepare a working standard solution $(100 \mu \mathrm{g} / \mathrm{mL})$.

\section{Method A (Zero order spectrometry)}

Series dilutions of standard solutions were prepared in $10 \mathrm{~mL}$ volumetric flasks with buffer ( $\mathrm{pH} 3.5$ ) to get the concentration ranging from $0.1-100 \mu \mathrm{g} / \mathrm{mL}$. The above solutions were scanned over the range of $400 \mathrm{~nm}$ to $200 \mathrm{~nm}$ against reagent blank. The $\lambda_{\max }$ was found to be $282.0 \mathrm{~nm}$ and the results were in good agreement with Beer-Lambert's law. The calibration curve was constructed by plotting concentration against absorbance at $282.0 \mathrm{~nm}$ (Figure 2).

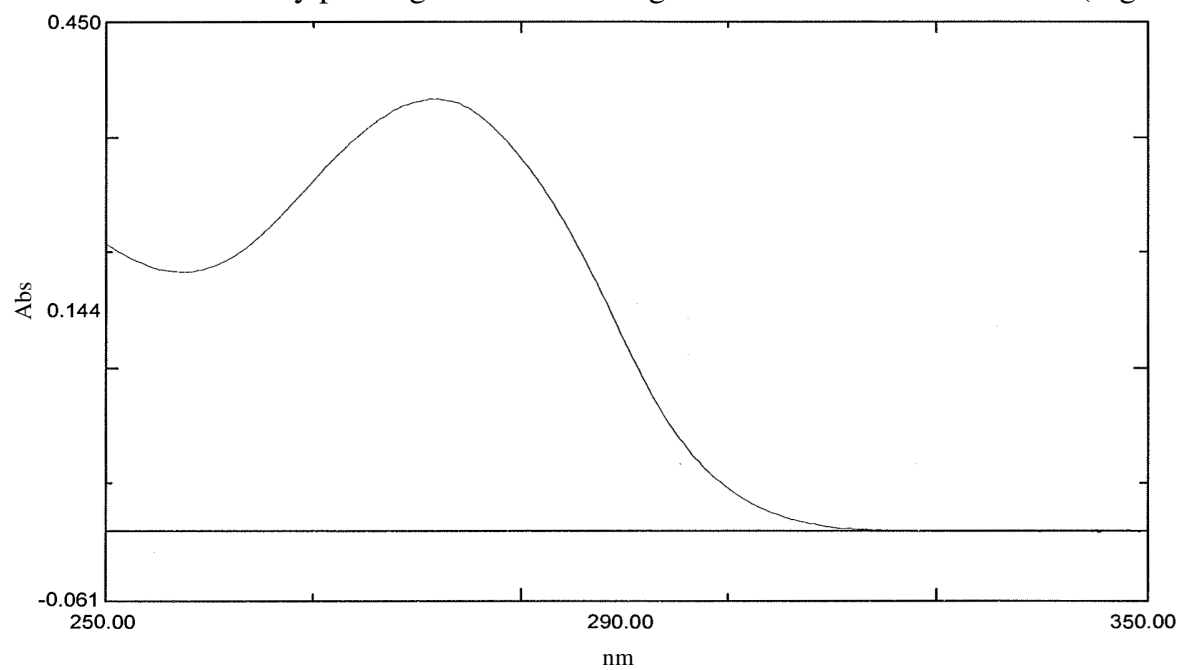

Figure 2. Zero- derivative absorption spectrum of emtricitabine $(10 \mu \mathrm{g} / \mathrm{mL})$

\section{Method B (First-derivative spectrometry)}

The above mentioned zero order spectrum were derivatised to get first-order derivative spectra (Figure 3). This spectrum shows minima $(298 \mathrm{~nm})$ as well as maxima $(269 \mathrm{~nm})$ and therefore the amplitude was chosen for the analytical determinations. 


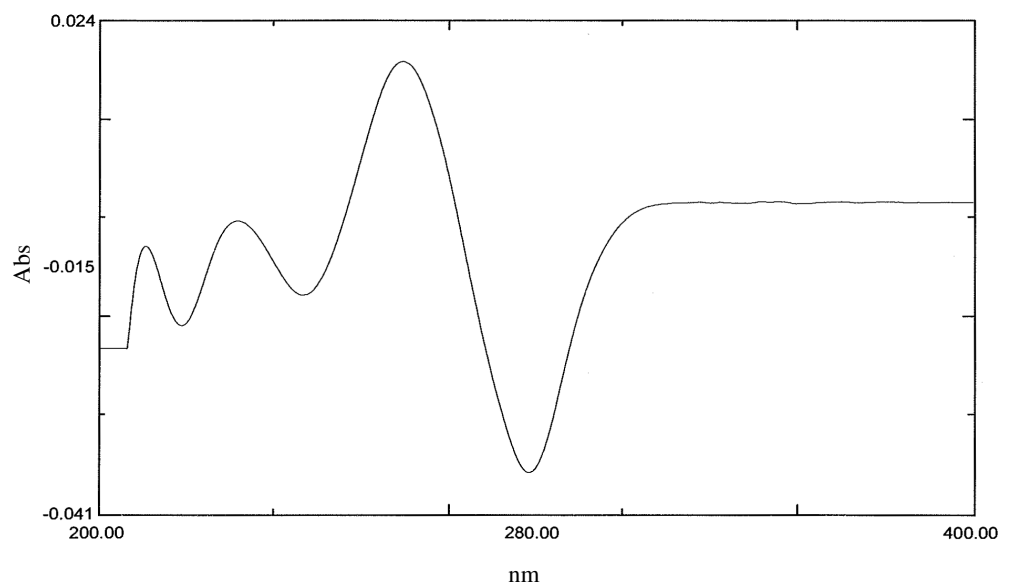

Figure 3. First- derivative absorption spectrum of emtricitabine $(10 \mu \mathrm{g} / \mathrm{mL})$

\section{Method C (Area under curve)}

The AUC (area under curve) method involves the value with respect to the selected wavelength region $(272-292 \mathrm{~nm})$. The calibration curve was constructed by potting concentration against AUC.

\section{Estimation of emtricitabine in tablets}

Twenty tablets were weighed, finely powdered and equivalent to $25 \mathrm{mg}$ of the drug was weighed from each brand and extracted with methanol, sonicated and make up to volume with methanol in three separate $25 \mathrm{~mL}$ volumetric flasks $(1 \mathrm{mg} / \mathrm{mL})$ and filtered. The dilutions were made from this stock with buffer ( $\mathrm{pH} 3.5)$, as per the requirement. Different sample solutions were prepared and analyzed against blank.

\section{Method validation}

\section{Precision}

The Inter-day precision was determined on three different days at three different levels $(10,20$ and $50 \mu \mathrm{g} / \mathrm{mL})$ and the intraday precision was determined at three different levels $(10,20$ and $50 \mu \mathrm{g} / \mathrm{mL})$ by the same analyst. The \%RSD values were found to be in the range $0.42-0.73$ (Intraday) and 0.56-0.92 (Interday) which are less than $2 \%$ indicating that the mehtod is more precise.

\section{Accuracy}

Recovery studies were carried out by adding different amounts (80\%, 100\% and 120\%) of bulk samples of emtricitabine within the linearity range to pre analyzed formulation as per ICH guidelines and the \%RSD values were found to be less than $2 \%(0.56-1.28 \%)$ indicating that the method is more accurate.

\section{Results and Discussion}

The calibration curve was obtained for a series of concentration in the range of $0.1-100 \mu \mathrm{g} / \mathrm{mL}$ for all the three methods. It was found to be linear and hence, suitable for the estimation of the drug. The optical characteristics were summarized in Table 1. Regression analysis of Beer's law plot revealed a good correlation. The effects of various excipients generally present in the tablet dosage forms of EMT were investigated. 
Table 1. Optical characteristics of emtricitabine by the proposed method

\begin{tabular}{lcccc}
\hline \multirow{1}{*}{ Parameters } & \multirow{2}{*}{ Method A } & Method B & \multirow{2}{*}{ Method C } \\
& & Amplitude & \\
\hline Beer-Lambert's range, $\mu \mathrm{g} / \mathrm{mL}$ & $0.1-100$ & $0.1-100$ & $0.1-100$ \\
$\lambda$ max/ wave length range, $\mathrm{nm}$ & 282 & $269-298$ & $272-292$ \\
Molar absorptivity, L/mol.cm & $9.445 \times 10^{3}$ & $2.4724 \times 10^{2}$ & $2.0621 \times 10^{4}$ \\
Sandell's sensitivity, $\mu \mathrm{g} \mathrm{cm} \mathrm{cm}^{-2} / 0.001$ & 0.02618 & - & - \\
Abs & & & \\
Slope & 0.038 & 0.002 & 0.082 \\
Standard deviation of slope & 0.000587 & 0.000251 & 0.001509 \\
Intercept & 0.001 & 0.000 & 0.012 \\
Standard deviation of Intercept & 0.00104 & - & 0.000241 \\
Correlation coefficient & 0.9998 & 0.9999 & 0.9998 \\
\hline
\end{tabular}

The recovery from the formulation (Table 2) was found to be 99.96-99.99 for method A, 99.95-99.98 for method B and 99.97-100.96 for method C. The proposed methods were validated as per the ICH guidelines ${ }^{12}$. The precision was measured in terms of repeatability, which was determined at three levels $(10,20$ and $50 \mu \mathrm{g} / \mathrm{mL}) \backslash$ and the $\%$ RSD were found to be less than 2.0\% (0.42- 0.73 (Intraday) and 0.56-0.92 (Interday)) showing that the method is more precise. The accuracy study was conducted by adding known quantities of the standard EMT solution $(80 \%, 100 \%$ and $120 \%)$ to a particular concentration of preanalyzed formulations and the mixtures were analyzed and the $\%$ recovery values were found to be within the range of $98.27-100.83 \%(\% \mathrm{RSD}=0.56-1.28 \%)$. This showed that the recovery of EMT by the proposed method is satisfactory. Thus it can be concluded that the methods developed in the present investigation are simple, sensitive, accurate, rapid and precise. Hence, the proposed methods can be successfully applied for the estimation of emtricitabine in tablet dosage forms.

Table 2. Analysis of commercial formulation

\begin{tabular}{|c|c|c|c|c|c|c|c|c|c|c|}
\hline \multirow{3}{*}{ Brand } & \multirow{3}{*}{$\begin{array}{c}\text { Labelled } \\
\text { Amount, } \\
\text { mg }\end{array}$} & \multicolumn{3}{|c|}{$\begin{array}{c}\text { Amount } \\
\text { Obtained, mg }\end{array}$} & \multicolumn{3}{|c|}{$\begin{array}{c}\text { Amount } \\
\% \text { Recovery }\end{array}$} & \multicolumn{3}{|c|}{$\% \mathrm{RSD}$} \\
\hline & & \multicolumn{3}{|c|}{ Method } & \multicolumn{3}{|c|}{ Method } & \multicolumn{3}{|c|}{ Method } \\
\hline & & $\mathrm{A}$ & B & $\mathrm{C}$ & $\mathrm{A}$ & B & $\mathrm{C}$ & $\mathrm{A}$ & B & $\mathrm{C}$ \\
\hline I & 200 & 199.91 & 199.89 & 199.83 & 99.99 & 99.98 & 99.97 & 0.86 & 0.65 & 0.76 \\
\hline II & 200 & 199.73 & 199.86 & 199.78 & 99.96 & 99.95 & 100.96 & 0.98 & 0.57 & 0.93 \\
\hline
\end{tabular}

\section{Conclusion}

Emtricitabine obeys Beer-Lambert's law in the concentration range of $0.1-100 \mu \mathrm{g} / \mathrm{mL}$ in all the four methods and the \%RSD in precision and accuracy studies was found to be less than $2.0 \%$ indicating that the methods are more precise and accurate and therefore, can be employed for the estimation of emtricitabine in pharmaceutical formulations.

\section{Acknowledgement}

Authors are grateful to Pharma Train Labs, Hyderabad for providing research facilities. The authors are also thankful to Piramal HC (India) for providing gift samples of the pure drug. 


\section{References}

1. The Merck Index, An Encyclopedia of Chemicals, Drugs and Biologicals, Maryadele J.O' Neil, Eds., 14 ${ }^{\text {th }}$ Ed., Published by Merck Research Laboratories, Division of Merck and Co. Inc., Whitehouse Station, N J, 2006.monograph No.3565, 607.

2. Li Y P, Li Z R, Cao Y, Shan G Z and Shao H Y, Yaowu Fenxi Zazhi, 2006, 26(11), 1606-1608.

3. Seshachalam U, Haribabu B and Chandrasekhar K B, J Separation Sci., 2007, 30(7), 999-1004.

4. Arjun Goje, Sathis Kumar D, Yogeswaran. P, Sathyabrata Jena, David Banji and KNV Rao, Der Pharma Chemica, 2010, 2(2), 281-285

5. Ashenafi D, Verbeek A, Hoogmartens J and Adams E, J Separation Sci., 2009, 32(11), 1823-1830.

6. Droste J A H, Aarnoutse R E and Burger D M, J Liq Chromatogr Relat Technol., 2007, 30(18), 2769-2778.

7. Yadav M, Singhal P, Goswami S, Sharma P and Shrivastav P S, J AOAC Int., 2009, 92(6), 1681-1689.

8. Nagaraju P T, Channabasavaraj K P and Shantha Kumar P T, Int J Chem Tech Res.. 2011, 3(1), 18-23.

9. Hemlata M. Nimje, Rajesh J Oswal and Mahesh B Fadake, Int J Pharma Res Develop., 2010, 2(8), 77-79.

10. Murali P, Dunge A M, Jos H, Ann V S, Erwin A, Talanta, 2010, 82(1), 125-128.

11. Sparindans R W, Prins J M, Schellenes J H M and Beijnen J H, Biomed Chromatogr., 2007, 21(6), 621-627.

12. International Conference on Harmonization of Technical Requirements for Registration of Pharmaceuticals for Human Use (Nov. 6,) Validation of Analytical Procedures: Methodology, ICH Steering Committee, Geneva, Switzerland. 1996. 